\title{
Laser Photoacoustic Method for Disc Tree-Ring Gas Analysis
}

\author{
B. G. Ageev, Yu. N. Ponomarev, V. A. Sapozhnikova* \\ V.E. Zuev Institute of Atmospheric Optics of Siberian Branch of the Russian Academy of Sciences, Tomsk, Academician Zuev Square, \\ 1, 634021, Russia
}

\begin{abstract}
A laser photoacoustic gas analysis was used to study the annual $\mathrm{CO}_{2}$ and $\mathrm{H}_{2} \mathrm{O}$ trends in tree rings and their comparison with the tree ring width of dry discs was made. The measurements show that 1 ) the $\mathrm{CO}_{2}$ concentration in gas samples vacuum-extracted from annual tree rings correlates with atmospheric $\mathrm{CO}_{2}$ rise in certain cases; approximately 4year cycles in $\mathrm{CO}_{2}$ distribution were readily fixed; 2) for the Scots pine discs, years with small tree ring width are characterized by high $\mathrm{CO}_{2}$ concentration, while those with large tree ring width are associated with small $\mathrm{CO}_{2}$ concentration. Abrupt changes in atmospheric conditions are assumed to favour increased amplitudes of one of natural cycles of annual $\mathrm{CO}_{2}$.
\end{abstract}

Keywords $\mathrm{CO}_{2}$, annual tree rings, laser photoacoustic method

\section{Introduction}

Current period is extremely interesting from the viewpoint of studying the effect of sharply changing atmospheric conditions on plants: changes in $\mathrm{CO}_{2}$ in the atmosphere and those in the $\mathrm{C}$ isotope ratio in $\mathrm{CO}_{2}$ are likely to affect plant photosynthesis and to give rise to changes in certain plant parameters as a response to stress.

Tree rings are generally considered as records of past climatic conditions and environmental changes[1]. However, researchers encounter some problems in studying the effect of atmospheric $\mathrm{CO}_{2}$ rise on the plants or in estimating the internal and external $\mathrm{CO}_{2}$ release by stems[2]. The atmospheric $\mathrm{CO}_{2}$ rise and climate warming are expected to enhance the annual growth of tree ring widths, which is not the case, however. In particular, Schweingruber[3] wrote, that: “. $\ldots$ the fact remains that none of the many studies from the northern and southern hemisphere show for the last 500 years an unexplainable growth increase that is clearly symptomatic of the modern climate change or of $\mathrm{CO}_{2}$ - fertilization". As Gedalof and Berg have noted in their work[4], a direct $\mathrm{CO}_{2}$ fertilization effect is traceable in as little as $20 \%$ of the areas around the globe.

The atmospheric $\mathrm{CO}_{2}$ concentration $(0.04 \%)$ is known to be lower than the $\mathrm{CO}_{2}$ content in stems, where it may be as high as $20 \%$ and more. Except for gas-phase $\mathrm{CO}_{2}$, a large amount of $\mathrm{CO}_{2}$ in stems is dissolved in xylem sap. Most $\mathrm{CO}_{2}$ within stems originates from respiring cells in stems

* Corresponding author:

sapo@asd.iao.ru (V.A. Sapozhnikova)

Published online at http://journal.sapub.org/env

Copyright (C) 2012 Scientific \& Academic Publishing. All Rights Reserved and roots. It is well established now that a large amount of respired $\mathrm{CO}_{2}$ is transported upward in a transpiration stream, and some portion of $\mathrm{CO}_{2}$ is fixed in green woody tissues/ leaves before it can diffuse to the atmosphere[5]. At the same time, the vacuum method used in our investigations for gas sample extraction from the annual ring wood showed that a certain amount of $\mathrm{CO}_{2}$ remained in dry old discs and exhibited a specific annual distribution. We have hypothesized that this distribution is the result of atmospheric parameter changes: atmospheric $\mathrm{CO}_{2}$ rise alters the annual concentration gradient between the atmospheric and stem-contained $\mathrm{CO}_{2}$. Hence, the dynamics of this process is likely to cause the annual $\mathrm{CO}_{2}$ changes in stems. There are many papers aimed at estimating the $\mathrm{CO}_{2}$ release to the atmosphere by stems, however, to our knowledge, none of them deals with annual $\mathrm{CO}_{2}$ trend estimations inside stems.

Using our laser photoacoustic spectrometer with a tunable $\mathrm{CO}_{2}$ laser, it is possible to trace the annual $\mathrm{CO}_{2}$ trend in discs and to characterize the $\mathrm{H}_{2} \mathrm{O}$ distribution over tree rings. The water content in discs of living trees has been studied by different methods (e.g., by computer X-ray tomography[6]). However, we are not aware of any attempts to characterize the annual water distribution over rings in dry discs. It should be noted that the method suggested here was tested not only on dry discs, i.e., those stored under laboratory conditions for a few years, but on a disc of a living tree as well.

A laser photoacoustic analysis based on different laser sources is a modern gas-detection tool used successfully in many applications for a long time[7-13]. We were the first to use this method for measuring the annual $\mathrm{CO}_{2}$ content and determining the $\mathrm{H}_{2} \mathrm{O}$ trends in disc rings of some coniferous trees. A plausible explanation of small tree ring 
growth appears to be stress situation (atmospheric $\mathrm{CO}_{2}$ rise and $\mathrm{C}$ isotope ratio change) leading to a $\mathrm{CO}_{2}$ accumulation inside stems due to "possible shifts in respiration"[14].

This work compares measurements of the $\mathrm{CO}_{2}$ content in annual tree rings of dry discs of the Siberian stone pine, Scots pine, and living Scots pine. A correlation between the $\mathrm{CO}_{2}$ content measurements and atmospheric $\mathrm{CO}_{2}$ rise is analyzed, the characteristics of the annual $\mathrm{H}_{2} \mathrm{O}$ distribution over disc tree rings are presented, and the carbon isotope content of $\mathrm{CO}_{2}$ desorbed from tree rings of discs is estimated.

The measurement results can be used by dendrochronologists, dendroecologists, and those dealing with carbon budget and carbon dioxide flux estimation between terrestrial ecosystems and the atmosphere. Hopefully, they will increase the reliability of tree ring data as proxies for environmental conditions.

\section{Material and Methods}

The $\mathrm{CO}_{2}$ content in gas samples extracted under vacuum from tree rings was measured in a Siberian stone pine dry disc, two Scots pine dry discs and a newly sawed Scots pine disc. The Siberian stone pine disc was sawed at a height of $1.5 \mathrm{~m}$, and two Scots pine dry discs (No.6 and No.12) were sawed at a height of $60 \mathrm{~cm}$ and $1.4 \mathrm{~m}$ above the ground, respectively. The newly sawed Scots pine disc (pine 2011) was sawed from a pine tree broken by the wind in the spring of 2011 at a height of $70-80 \mathrm{~cm}$ above the ground. All discs were sawed near Tomsk (West Siberia, Russia). The dry discs were stored from 6 months to a few years under laboratory conditions, so the wood material can be considered to be room-dried. The time series studied spanned 100 years for the Siberian stone pine, 104 and 90 years for two dry Scots pine discs and 55 years for the newly sawed pine disc.

The measurements were performed using a computercontrolled laser photoacoustic (PA) spectrometer with a frequency-tunable waveguide $\mathrm{CO}_{2}$ laser[15]. PA spectroscopic methods offer essential advances in pollutant gas monitoring[7-9,16-18]. The PA signal originates from the non-radiative de-excitation of the energy absorbed by gas in optical transitions, the absorbed power is determined directly via heat, and sound is generated in a gas sample. The acoustic waves are then measured by a cell microphone. Therefore, the PA spectrum can be correlated with optical absorption spectra of the sample[18]. Once the system is calibrated, i.e., the absorption in gases with known concentrations is measured and the calibration coefficient is found, the absorbing component concentration in the gas sample studied is determined.

The spectrometer setup (Fig.1) and measurement procedure were standard for PA gas absorption measurements. The sealed-off RF-excited waveguide $\mathrm{CO}_{2}$ laser with computer controlled tuning frequency and stabilization to the centre of the line chosen was used as a light source[15]. It was found experimentally that such lasers have a high constructive rigidity and low sensitivity to external mechanical impacts. A gold-coated reflecting grating with a period of $150 \mathrm{~mm}^{-1}$ is used as a back laser mirror.

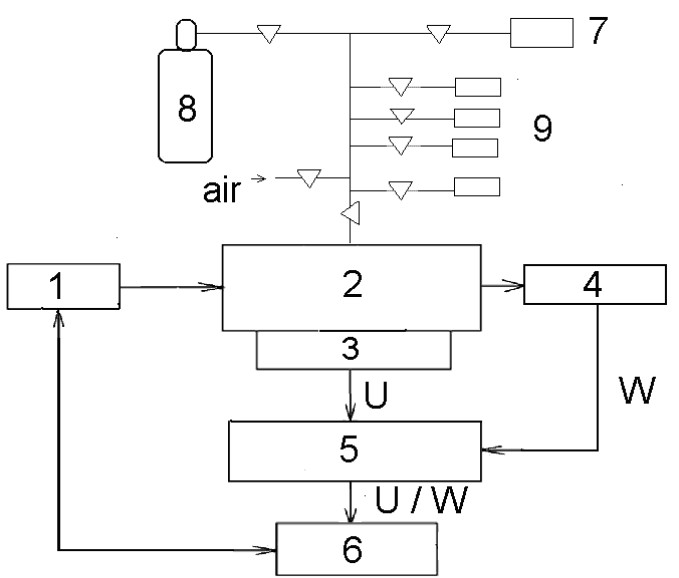

Figure 1. Block-diagram of the PA-Laser spectrometer: $1-\mathrm{a} \mathrm{CO}_{2}$ Laser, 2-a photoacoustic cell, 3 -a microphone, $4-$ a photodetector, $5-$ a system for measuring and recording electric signals, $6-$ a computer, 7a pump, $8-\mathrm{CO}_{2} / \mathrm{N}_{2}$ reference mixture, $9-$ exposure chambers

The laser emits more than 70 lines within a tuning spectral range of $9.2-10.8 \mu \mathrm{m}$ with an output power of $0.3-3$ $\mathrm{W}$ in a single-mode single-frequency regime. Laser radiation is modulated via amplitude modulation of a pump power high-frequency (RF-) generator. An attenuator (Ge or $\mathrm{BaF}_{2}$ ) is placed in front of a PA-cell so that the modulated $\mathrm{CO}_{2}$ laser radiation is $\sim 70 \mathrm{~mW}$ before passing through the cell. A nonresonance photoacoustic detector is used for measuring the absorption photoacoustic signal $\mathbf{U}$. A detector made from stainless steel consists of a cylindrical gas PA-cell $(\varnothing 10 \times 100 \mathrm{~mm})(2)$ and is connected to a microphone cell (3), where a homemade plane capacitor microphone is placed. $\mathrm{BaF}_{2}$ windows are mounted at both ends of the PA-cell. Low $(123 \mathrm{~Hz})$ modulation frequency of radiation is selected to increase the signal-to-noise ratio of the PA-detector[16]. Another photoacoustic detector (4) is used to measure the laser power $\mathbf{W}$. The photodetector design is similar to the gas PA-cell, except that the chamber with a nonselective absorber (blackened metal foil) is used instead of a gas. The photoacoustic detector signals $\mathbf{U}$ and $\mathbf{W}$ are amplified by wideband amplifiers and fed into the measuring and recording system based on a computer sound card. Laser line tuning, detector signal recording and preliminary processing (averaging, ratio determination) are performed by means of special software.

The measurement results are stored in a file containing the values of $\mathbf{A}=\mathbf{U} / \mathbf{W}$ for the corresponding laser lines, yielding an analog of the absorption spectrum in the sample. Information about the spectrum is displayed on a computer monitor to visualize the spectrometer data.

The system is pre-calibrated using a $\mathrm{CO}_{2} / \mathrm{N}_{2}$ reference mixture containing a known amount of $\mathrm{CO}_{2}$. The PA cell is filled with the reference mixture of $\mathrm{CO}_{2}$ concentration, and the values of $\mathbf{A}=\mathbf{U} / \mathbf{W}$ and $\mathrm{CO}_{2}$ concentration in the mixture 
used are compared for selected laser lines. The ultimate absorption coefficient sensitivity of the spectrometer used was $2 * 10^{-5} \mathrm{~cm}^{-1}$ for a laser power of $70 \mathrm{~mW}$, and the calibration measurement error did not exceed $\pm 5 \%$.

Gas samples were prepared in the following way. The wood of tree rings was placed in four sealed exposure chambers pumped out for a short time to stimulate sorbed gas diffusion, and 20 minutes later the measurements were performed[19].

In all measurements, the gas samples from each exposure chamber (at a pressure of $\sim 800-1100 \mathrm{~Pa}$ ) were admitted to an evacuated PA cell to which air was added to get a total pressure of $13300 \mathrm{~Pa}$ in the cell so that a maximum sensitivity of the PA cell was reached. Every $\mathbf{A}$ ring measurement series in the wood-extracted sample studied was accompanied by measurements of background air absorption $\mathbf{A}_{\text {air. }}$. The information-bearing value was $\mathbf{D A}=\mathbf{A}$ ring $-\mathbf{A}_{\text {air }}$ from which the relative $\mathrm{CO}_{2}$ concentration in the sample was determined using a calibration curve. Signals were recorded from four tunable $\mathrm{CO}_{2}$ laser lines: $10 \mathrm{P}(20,16,14)$ (coinciding with $\mathrm{CO}_{2}$ absorption lines) and $10 \mathrm{R} \mathrm{(20)} \mathrm{(coinciding}$ with an $\mathrm{H}_{2} \mathrm{O}$ vapor absorption line). The $\mathrm{H}_{2} \mathrm{O}$ absorption coefficients in the $10 \mathrm{P}(20,16,14)$ lines was much lower than the $\mathrm{CO}_{2}$ absorption coefficients in these lines[20]. Thus, $\mathrm{H}_{2} \mathrm{O}$ is considered to make a minor contribution to the $\mathrm{CO}_{2}$ absorption in the $10 \mathrm{P}(20,16,14)$ lines under our experimental conditions. Measurements in $10 \mathrm{P}$ (14) were made to detect a possible appearance of the signal from ethylene, whose absorption coefficient in $10 \mathrm{P}(14)$ is $10^{3}$ times higher than that of $\mathrm{CO}_{2}$.

To verify the fact that $\mathrm{CO}_{2}$ in the samples studied was generated by the tree itself and not supplied from the atmosphere, an isotope analysis of the carbon $\left(\delta^{13} \mathrm{C}\right) \mathrm{CO}_{2}$ for a few rings was performed. Terrestrial plants $\left(\mathrm{C}_{3}\right.$ type, including conifers) are known to be characterized by a range of carbon isotope compositions $\left(\delta^{13} \mathrm{C}\right)$ from approximately $-22 \%$ to $-32 \%$, whereas the atmospheric carbon isotope composition is on average $-8.07 \%[21]$ with respect to standard Pee Dee belemnite (PDB)[22]:

$$
\delta^{13} \mathrm{C},(\%)=\left[\left(\mathrm{R}_{\text {sample }} / \mathrm{R}_{\text {standard }}\right)-1\right]^{*} 1000
$$

To study the isotope composition, $\mathrm{CO}_{2}$ was desorbed from a tree ring in a nitrogen atmosphere at $T=80^{\circ} \mathrm{C}$. The stable carbon isotope ratio $\left(\delta^{13} \mathrm{C}\right)$ of the wood $\mathrm{CO}_{2}$ was measured at Laboratory of Isotopic Methods of Tomsk Branch of FSUB SRIGGMR (Certificate No. ROSS RU 001 517930), using a DELTA V Advantage mass spectrometer, to within \pm 0.5 for a confidence probability of 0.95 .

The tree ring widths were measured on disc surfaces by a LINTAB measuring system within an accuracy of $0.01 \mathrm{~mm}$.

\section{Results}

\subsection{Temporal Variations of Signals}

We have performed a preliminary analysis of the gas reabsorption rate from a sample and its possible reciprocal sorption by the wood in exposure chambers. To this end, four exposure chambers filled with wood material, approximately homogeneous and equal in mass, were simultaneously subjected to short-term pumping-out, and during a certain time were under vacuum. Figure 2 presents normalized results of the signal variations with time for different $\mathrm{CO}_{2}$ laser lines for these four exposure chambers.

The $\mathrm{H}_{2} \mathrm{O}$ signal in short-term vacuum peaked within approximately $25 \mathrm{~min}$, and then reabsorption began. In the other three lines, where the $\mathrm{CO}_{2}$ signal was recorded, it reached its maximum only within $\sim 2.5 \mathrm{~h}$, and then the reabsorption started again. While the values of the $\mathrm{CO}_{2} \mathrm{ab}-$ sorption coefficients in the laser lines were very close, there was a marked difference between the gas sample absorption at the same wavelength. This is evidence of an organic wood material inhomogeneity in different exposure chambers.

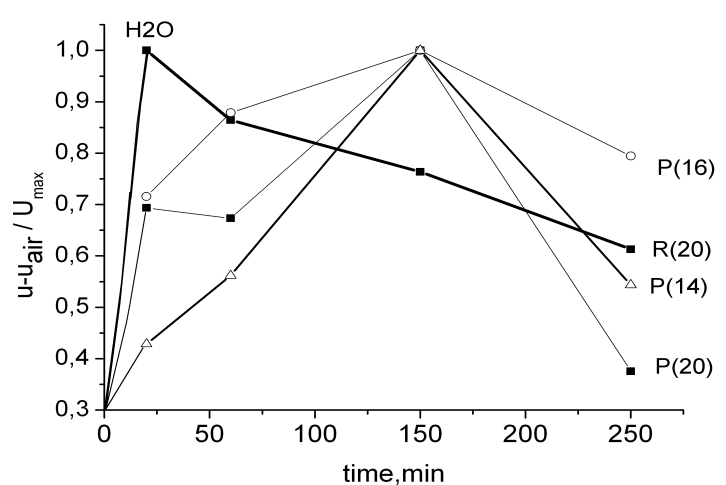

Figure 2. Temporal variations of signals from components reabsorbed from a disc at four $\mathrm{CO}_{2}$ laser lines

\subsection{Measurements of $\mathrm{CO}_{2}$ Content in Disc Tree Rings}

The measured relative tree ring $\mathrm{CO}_{2}$ concentrations in the disc gas samples studied are shown in Figures 4, 5, 6, 7 and 8. The trends in carbon isotope composition $\delta^{13} \mathrm{C}$ and atmospheric $\mathrm{CO}_{2}$ (curve 1)[21] and NOAA data (curve 2) are illustrated in Fig. 3.

The annual $\mathrm{CO}_{2}$ variations and annual behavior of the tree ring width of spruce[23] are also shown in Figure 8 for comparison. It is evident from Figs $4-8$ that the $\mathrm{CO}_{2}$ concentration in the tree rings is higher than the atmospheric $\mathrm{CO}_{2}$ and that a noticeable annual trend in $\mathrm{CO}_{2}$ exists. $\mathrm{A}$ comparison of the data for the Siberian stone pine ring widths and annual concentration of $\mathrm{CO}_{2}$ extracted from tree rings shows that a rapid rise of the $\mathrm{CO}_{2}$ content occured after 1960, when the tree ring widths were minimal (Fig. 4). At the same time, the $\mathrm{CO}_{2}$ concentration in dry discs of the Scots pine (Figs 5 and 6) increased up to 1960 (the data were taken as averages over 3 spectral lines), and then the $\mathrm{CO}_{2}$ concentration decreased drastically down to a constant level of $1000 \mathrm{ppm}$ (pine 12) or showed a slow rise (pine 6). Figures 5 and 6 for the Scots pine demonstrate the main tendencies in the $\mathrm{CO}_{2}$ distribution over rings: 1) all data on the annual $\mathrm{CO}_{2}$ concentration for pine up to 1960 exhibit distinct cycles with $\sim 4$-year period; 2 ) the tree ring widths and $\mathrm{CO}_{2}$ concentration in the Scots pine discs (Nos. 6 and 12) vary, roughly speaking, in "antiphase": years with small 
tree ring widths show high $\mathrm{CO}_{2}$ concentrations, and vice versa.

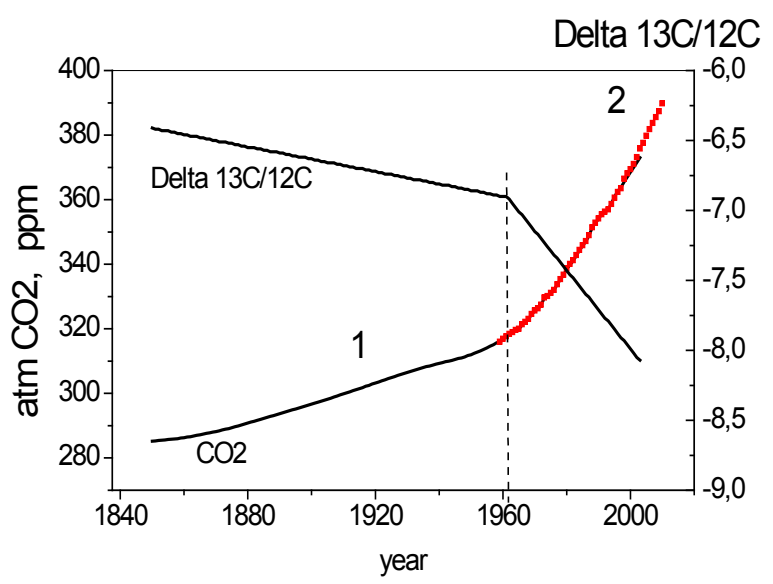

Figure 3. Trends in the stable carbon isotope ratio $\delta^{13} \mathrm{C}$ (delta 13C) and atmospheric $\mathrm{CO}_{2}$ [21] (curve 1) and NOAA data (curve 2) [ftp://ftp.cmdl. noaa.gov/ccg/co2/trends/co2_annmean_mlo.txt ].

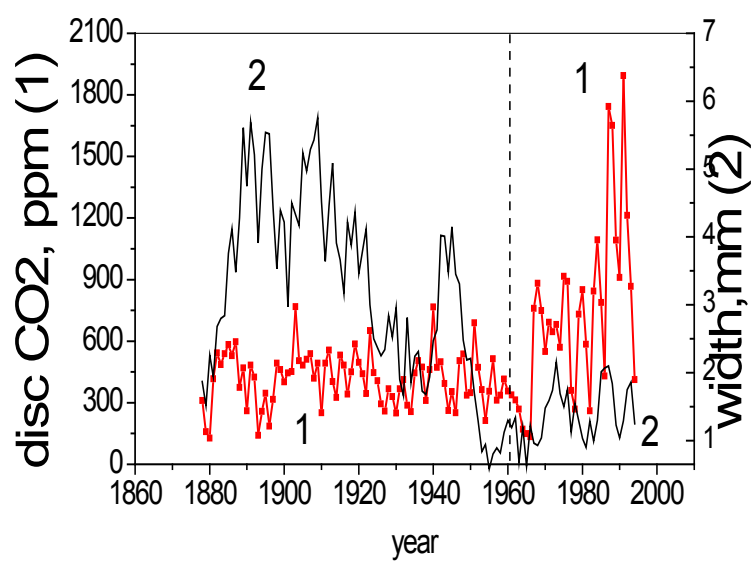

Figure 4. Annual variations in the tree ring $\mathrm{CO}_{2}$ content (curve 1) and width (curve 2) in a Siberian stone pine disc

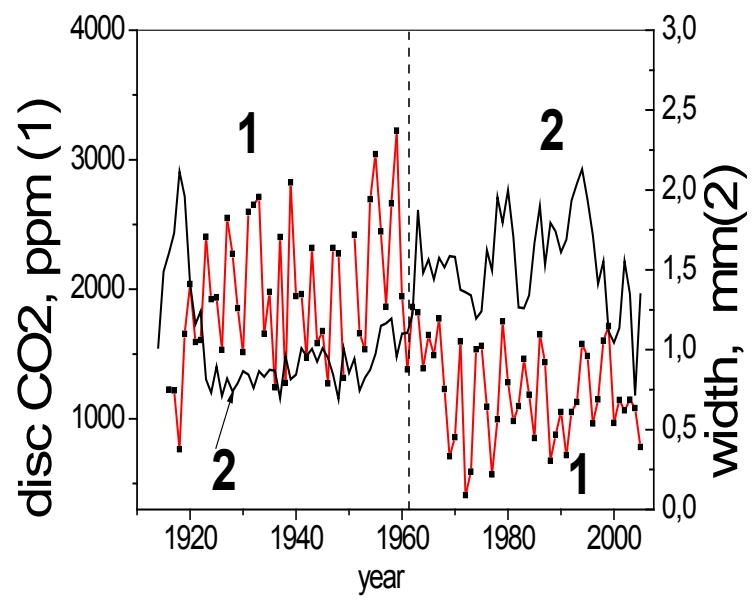

Figure 5. Annual variations in the tree ring $\mathrm{CO}_{2}$ content (curve 1 ) and width (curve 2) in a Scots pine disc No. 6

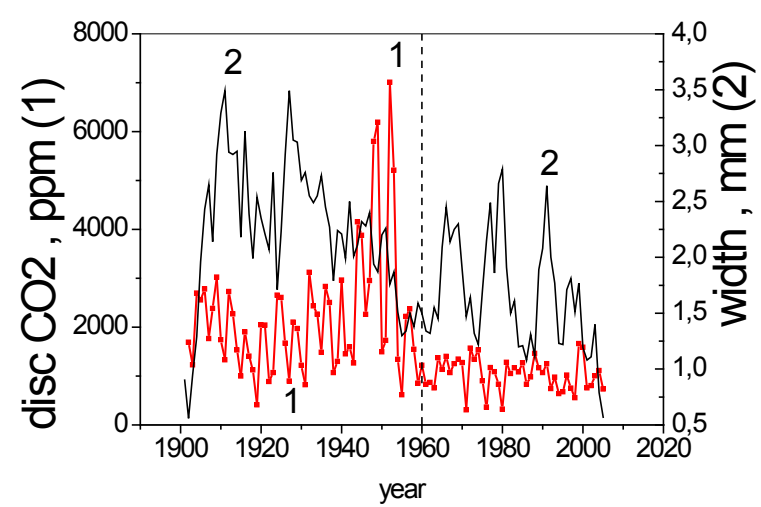

Figure 6. Annual variations in the tree ring $\mathrm{CO}_{2}$ content (curve 1) and width (curve 2) in a Scots pine disc No. 12

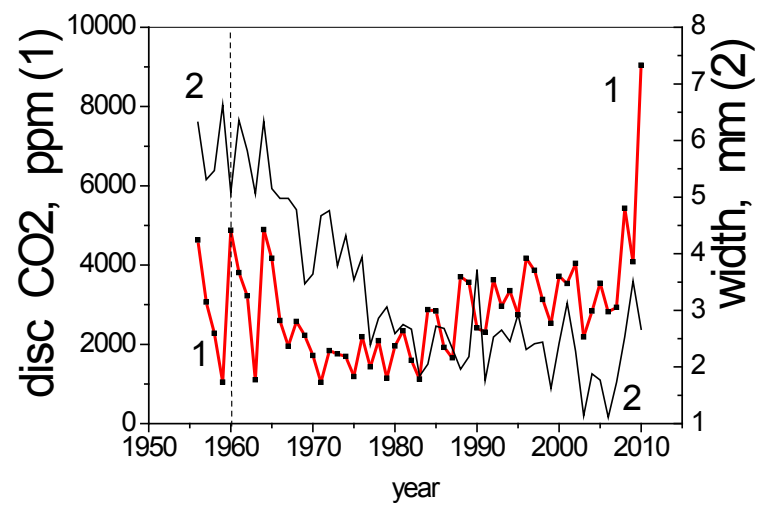

Figure 7. Annual variations in the tree ring $\mathrm{CO}_{2}$ content (curve 1) and width (curve 2) in newly sawed Scots pine disc (pine-2011)

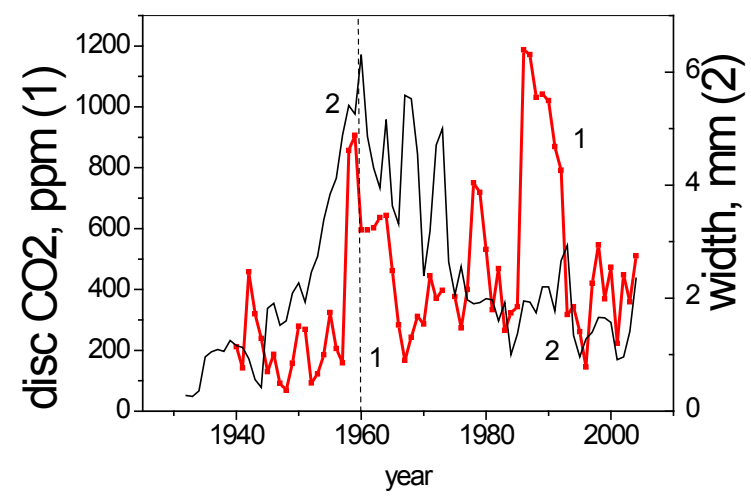

Figure 8. Annual variations in the tree ring $\mathrm{CO} 2$ content (curve 1) and width (curve 2) in spruce No. 25

For a newly-sawed Scots pine disc (Fig. 7), the $\mathrm{CO}_{2}$ concentration was high in wide tree rings of the early growth stage between 1956 and 1965 (positive coefficient correlation $\mathrm{R}=0.45, \mathrm{P}=0.0449, \mathrm{~N}=20$ ). On the contrary, in 1970 2010, the $\mathrm{CO}_{2}$ annual content increased, whereas the tree ring width decreased in the pine studied $(\mathrm{R}=-0.34$, $\mathrm{P}=0.002751, \mathrm{~N}=41$ ). Thus, all discs show $\mathrm{CO}_{2}$ rise, with the $\mathrm{CO}_{2}$ concentration reaching $3000-8000 \mathrm{ppm}$ in the Scots pine discs around 1960. The data on the $\mathrm{CO}_{2}$ distribution in 
the spruce tree rings (Fig. 8) also show a maximum around 1960. Notably, there is a second maximum of the $\mathrm{CO}_{2}$ content (identified with a Voigt fit).

In our earlier work[24], we found a correlation between the annual trend in $\mathrm{CO}_{2}$ in fir tree discs and total stratospheric ozone concentration for the growing period after 1980. However, the observed increase in the $\mathrm{CO}_{2}$ concentration in the tree rings is attributable to atmospheric $\mathrm{CO}_{2}$ rise [25]. A comparison of the tree ring $\mathrm{CO}_{2}$ data obtained with those on the trend in the atmospheric $\mathrm{CO}_{2}$ for Mauna Loa (2008, http://cdiac.ornl.gov/ftp /trends/co2/maunaloa.co2) and NOAA results showed their correlation: positive correlation coefficients varied in the range $\mathrm{R}=0.5-0.73(\mathrm{P}=$ $0.002-0.01$ ) for all spruce discs[23], and a significant correlation of the coefficient $\mathrm{R}=0.63(\mathrm{P}<0.0001)$ was found for the Siberian stone pine. A comparison of the trend in $\mathrm{CO}_{2}$ for the Scots pine discs with atmospheric $\mathrm{CO}_{2}$ showed a weak positive correlation between them until $1960(\mathrm{R}=$ $0.39, \mathrm{P}=0.0081$ for pine No. 6 and $\mathrm{R}=0.40, \mathrm{P}=0.00321$ for pine No. 12), but an insignificant correlation was established after 1960. However, a slight $\mathrm{CO}_{2}$ rise in the disc tree rings of pine No. 6 was observed. For the living tree disc (pine-2011), there was a weak correlation between the tree ring $\mathrm{CO}_{2}$ and atmospheric $\mathrm{CO}_{2}$ rise in $1959-2010: \mathrm{R}=$ $0.46, \mathrm{P}=5.35863 * 10^{-4}$. Comparison of the $\mathrm{CO}_{2}$ measurements for all discs of different conifers shows that sudden changes in the atmospheric conditions (Fig. 3) intensify one of the cyclic processes (e.g., with the 30-year period, see Figure 8), whose first maximum appears in the 1960s (Fourier analysis has shown the presence of harmonic oscillations with periods of 2, 4, 16.5, 23.5 and 29 years in the tree ring $\mathrm{CO}_{2}$ distributions[19]). There is no second maximum for dry discs of the Scots pine. This may be due to $\mathrm{CO}_{2}$ actively accumulated around the first maximum somewhere around 1960. For the pine-2011 disc, $\mathrm{CO}_{2}$ was found to rise after 1970, supposedly, indicating the development of the second maximum

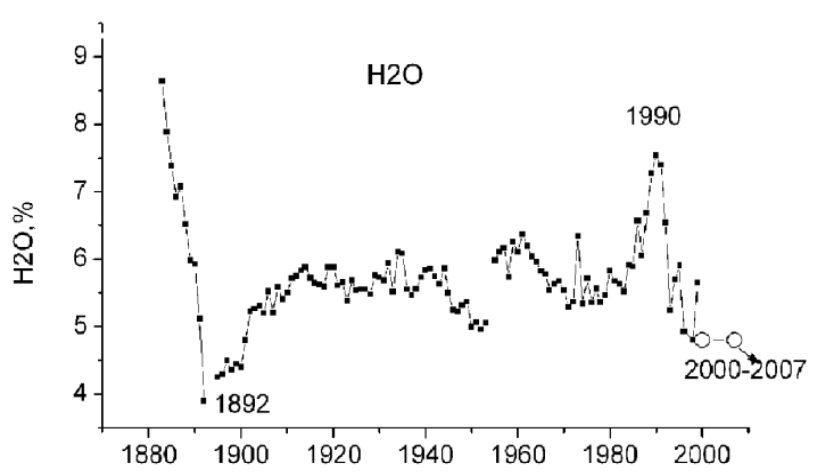

Figure 9. Variation of water content in Siberian stone pine tree rings

\subsection{Trend in $\mathrm{H}_{2} \mathrm{O}$ in Disc Tree Rings}

Results on the annual water content in Siberian stone pine rings obtained by the classical method of sample drying up to a perfectly dry state are presented in Fig. 9. Data for 1954 are excluded because of a high water content due to increased resin concentration. The tree rings for recent years also contain a lot of resin. It was shown that there existed a weak correlation between water content in the Siberian stone pine disc and summer precipitations during $1896-1960(\mathrm{R}=0.20 ; \mathrm{P}=0.10926)$. A high correlation $(\mathrm{R}$ $\left.=-0.88, \mathrm{P}=8.69396 * 10^{-4}\right)$ exists between the water content in disc rings and the ring width in the beginning of the tree growth $(1883-1896)$, and a weak correlation for other years $(\mathrm{R}=-0.41, \mathrm{P}<0.0001, \mathrm{~N}=103)$.

$\mathrm{CO}_{2}$ in plant tissues is known to exist both in gaseous and liquid phases[2]. Tuning of the $\mathrm{CO}_{2}$ laser line allows for detection of water vapour extracted simultaneously with $\mathrm{CO}_{2}$ from the tree rings under vacuum with the use of the 10R(20) laser line whose frequency coincides with the $\mathrm{H}_{2} \mathrm{O}$ absorption line center. Variations in signals $\mathbf{\Delta A}$ characterizing the $\mathrm{CO}_{2}$ laser absorption by $\mathrm{H}_{2} \mathrm{O}$ desorbed from the tree rings for the Siberian stone pine disc and Scots pine disc (No. 6) are illustrated in Fig. $10(a, b)$. Approximately 4year cycles are readily seen. At the same time, certain longperiod cycles were detected as well. Long-period cycles were roughly estimated using polynomial fits: the oscillation periods were $25-30$ years for the Siberian stone pine and $29-30$ years for pine. For the pine-2011 disc, a significant positive correlation was established between $\mathrm{CO}_{2}$ and $\mathrm{H}_{2} \mathrm{O}$ signals $(\mathrm{R}=0.88, \mathrm{P}<0.0001, \mathrm{~N}=55)$, suggesting that most of $\mathrm{CO}_{2}$ extracted from the pine-2011 disc tree rings is dissolved in water.

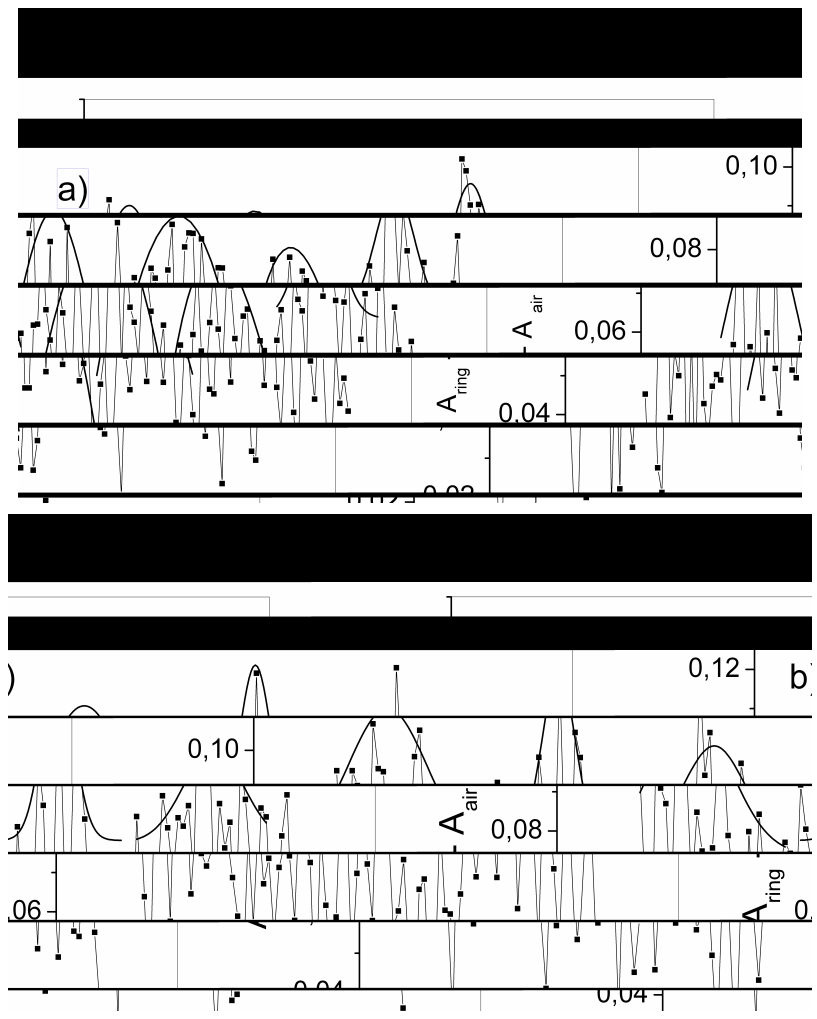

Figure $10(\boldsymbol{a}, \boldsymbol{b})$. Periodic variations of $\mathrm{H}_{2} \mathrm{O}$ signals for annual tree rings of (a) Siberian stone pine and $(b)$ Scots pine discs. Fitting is used for cycle detection

In contrast to the experiment where the water amount in tree rings was determined through the total drying for $48 \mathrm{~h}$ 
up to a perfectly dry state, in the case at hand we detected free water, that easily diffused into the exposure chamber during 20 min due to a decrease in the pressure.

\subsection{Variations of the Carbon Isotope Composition of $\mathrm{CO}_{2}\left(\delta^{13} \mathrm{C}\right)$}

Measurements of the carbon isotope composition of desorbed $\mathrm{CO}_{2}$ from the Siberian stone pine and Scots pine tree rings show variations of $\delta^{13} \mathrm{C}$ in the samples studied, on the average, in the $(-22.1)-(-36.6) \%$ range, thus strongly indicating generation of the desorbed tree-ring $\mathrm{CO}_{2}$ by the trees themselves. Measurements of the carbon isotope composition of $\mathrm{CO}_{2}$ desorbed from stone pine disc tree rings show that the carbon isotope composition changes practically immediately with $\mathrm{CO}_{2}$ content rise in the sample: the higher is the $\mathrm{CO}_{2}$ concentration in the sample, the lighter is its isotope composition, and vice versa (Fig. 11). Moreover, the carbon isotope composition of $\mathrm{CO}_{2}$ desorbed from the Siberian stone pine tree rings dated to the 1990s $(-36.6 \%$ o) turned out to be lighter than that dated to the 1920s (26.5\%) (Fig. 12). A similar tendency was noted for Scots pine No12 (- $25.4 \%$ in 1930 and -34.8 in 1969). This seems to be primarily due to age-related changes in biochemical reactions and in the associated processes of fractioning of the carbon isotopes[22,26-29].

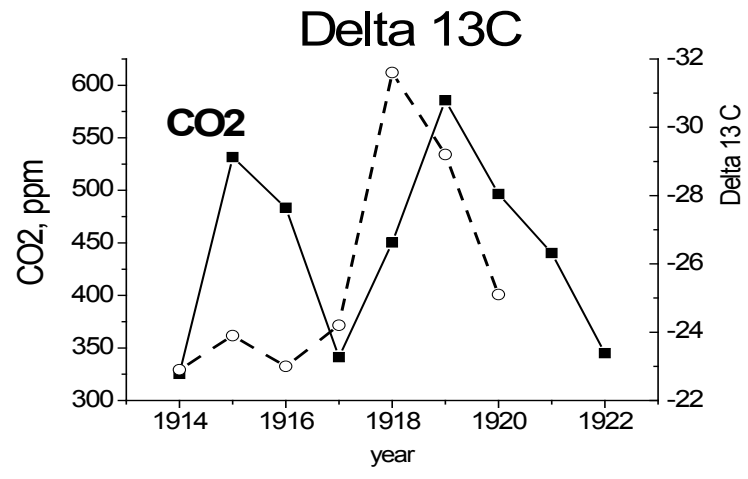

Figure 11. Variations of the carbon isotope composition of $\mathrm{CO}_{2}$ and $\mathrm{CO}_{2}$ content (ppm) in tree rings of the Siberian stone pine disc

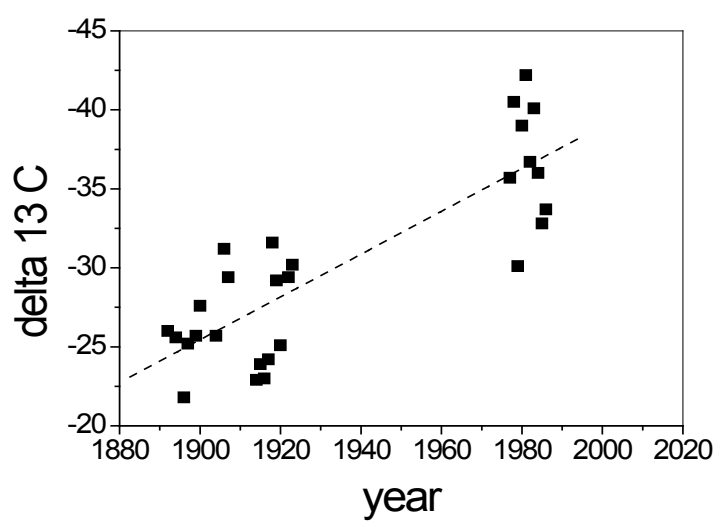

Figure 12. Variation of the isotope composition of the carbon of $\mathrm{CO}_{2}$ in gas samples of the 1920s and 1990s in tree rings of the Siberian stone pine disc

\section{Conclusions}

Our studies of the annual $\mathrm{CO}_{2}$ and $\mathrm{H}_{2} \mathrm{O}$ content in disc tree rings by the laser photoacoustic method suggest the following conclusions:

1) disc tree rings contain a certain amount of treeproduced $\mathrm{CO}_{2}$ whose concentration is higher than that of atmospheric $\mathrm{CO}_{2}$, that does not diffuse to the atmosphere;

2) the annual increase of the disc $\mathrm{CO}_{2}$ content correlates with atmospheric $\mathrm{CO}_{2}$ rise in certain cases;

3) based on a comparison of the $\mathrm{CO}_{2}$ data for all tree-ring discs, we can assume that changes in atmospheric conditions (rapid $\mathrm{CO}_{2}$ rise and carbon isotope $13 \mathrm{C} / 12 \mathrm{C}$ ratio variations) favour increased amplitudes of one of the natural cycles of the annual $\mathrm{CO}_{2}$ tree ring distribution in the stem whose first maximum lies somewhere in 1960. Naturally, the energy lost to maintain this process results in a smaller ring width;

4) if our assumption that the $\mathrm{CO}_{2}$ diffusion rate from the stem changes with atmospheric $\mathrm{CO}_{2}$ rise is correct, care should be taken in performing experiments on growing chambers where the effect of an excess $\mathrm{CO}_{2}$ content on plants is modeled. This is due to the fact that in some cases, the excess $\mathrm{CO}_{2}$ influences the tree ring width. It would be interesting to monitor the annual $\mathrm{CO}_{2}$ distribution and tree ring width in discs of this kind.

Thus, the use of the laser photoacoustic method provides a unique opportunity for studying the multiyear time series of the $\mathrm{CO}_{2}$ and $\mathrm{H}_{2} \mathrm{O}$ contents in conifer disc tree rings and obtaining valuable information on their relation to atmospheric parameters.

\section{ACKNOWLEDGEMENTS}

This work was supported by the Siberian Branch of the Russian Academy of Sciences (Project nos. VI.44.2.6, and VII.66.1.3).

We would like to thank Doctor Tikhomirov B.A. for providing sawn disc, Doctor Savchuk D.A. for providing discs and measuring the ring widths and the staff of Laboratory of Isotope Organic Geochemistry (Tomsk Department of Federal State Unitary Enterprise "Siberian Research Institute of Geology, Geophysics and Mineral Resources") for performing an isotope analysis.

\section{REFERENCES}

[1] Vaganov, E.A., Schulze, E.-D., Skomarkova, M.V., Knohl, A., Brand, W.A., and Roscer, C., 2009, Intra-annual variability of anatomical structure and $\delta 13 \mathrm{C}$ values within tree rings of spruce and pine in alpine, temperate and boreal Europe., Oecologia, 161, 729-745.

[2] Ping Zhao and Dirk Hölscher, 2009, The concentration and efflux of tree stem $\mathrm{CO}_{2}$ and the role of xylem sap flow., Front. Biol. China,4(1), 47-54. 
[3] F.H. Schweingruber, Tree ring and Environment. Dendroecology, Ed. Berne, Stuttgart,Vienna, Haupt, 1996.

[4] Gedalof, Z., and Berg, A.A., 2010, Tree ring evidence for limited direct $\mathrm{CO} 2$ fertilization of forests over the 20th century., Global Biochem.Cycles, 24 ,GB3027,1-6 .

[5] Teskey,R.O., Saveyn,A., Steppe,K., and McGuire,M.A., 2008, Origin, fate and significance of $\mathrm{CO} 2$ in tree stems., New Phytol. , 177, 17-32.

[6] Fromm, J.H., Sautter, I., Matthies, D., Kremer, J., Schumacher P., and Ganter, C., 2001, Xylem water content and wood density in spruce and oak trees detected by highresolution computed tomography., Plant physiol. 127, 416425 .

[7] Meyer, P.L., and Sigrist, M.W., 1990, Atmospheric pollution monitoring using $\mathrm{CO}_{2}$-laser photo acoustic spectroscopy and other techniques., Rev. Sci. Instrum. 61, 1779-1807.

[8] M.W. Sigrist (Ed.), Air Monitoring by Spectroscopic Techniques, Ed. New York, USA: Willey, 1994.

[9] F.J.M. Harren, G. Cotti, J. Oomens and S. te Lintel Hekkert, Photoacoustic Spectroscopy in Trace Gas Monitoring, Encyclopedia of Analytical Chemistry, Ed.,R.A. Meyers, Ed. Chichester, England:Wiley, 2000.

[10] Cernat, R., Matei, C., Bratu, A.M. , Popa, C., Dutu, D.C.A., Patachia, M., Petrus, M., Banita S., and Dumitras D.C., 2010, Laser photoacoustic spectroscopy method for measurements of trace gas concentration from human breath., Pomanian Reports in Physics, 62, 610-616.

[11] Sigrist, M.W., Bartlome, R. , Marinov, D., Rey, J.M., Vogler, D.E., and Wächter, H., 2008, Trace gas monitoring with infrared laser-based detection schemes., Appl. Phys. B 90, 289-300 , DOI: 10.1007/s00340-007-2875-4.

[12] G. R .Lima, M. S. Sthel, M. G. da Silva, D. U. S. Schramm, M. P. P. de Castro and H. Vargas, 2011, Photoacoustic spectroscopy of $\mathrm{CO} 2$ laser in the detection of gaseous molecules. IOP Publishing Journal of Physics: Conference Series 274, 012086,doi:10.1088/1742-6596/274/1/012086.

[13] Webber,M.E., MacDonald,T., Pushkarsky,M.B., Patel, C.K.N., Zhao,Y., Marcillac N., and Mitloehner F.M., 2005, Agricultural ammonia sensor using diode lasers and photoacoustic spectroscopy., Meas. Sci. Technol. 16 1547-1553. doi:10.1088/0957-0233/16/8/002.

[14] Jacoby G., and D'Arrigo,R., 1997, Tree rings, carbon dioxide, and climatic change., Proc. natl. Acad.Sci.USA, 94, 8350-8353, ColloquuimPaper.

[15] Sherstov, I.V., Bychkov, K.V., Vasil'ev, V.A., Karapuzikov, A.I., Spitsyn V.V. and Chernikov, S.B., 2005, Two-channel $\mathrm{CO} 2$ laser system for heterodyne lidar., Atm. Oceanic Opt. 18(3), 248-253 .

[16] West G.A., Barret, J.J., Siebert, D.R. and Reddy, K.V., 1983, Photoacoustic spectroscopy., Rev. Sci. Instrum., 54, 797817 .
[17] Zharov, V.P., and Letohokov, V.S., 1984, Laser Optoacoustic Spectroscopy., Moscow, Russia: Nauka.

[18] Van Neste, C.W., Senesac, L.R., and Thundat T.,2008, Standoff photoacoustic spectroscopy., Appl. Phys. Lett. 92, 234102 .

[19] Ageev, B.G., Zotikova, A.P., Padalko, N.L., Ponomarev, Yu.N., Savchuk,D.A., Sapozhnikova,V.A., and E.V. Chernikov, 2011,Variation of $\mathrm{H} 2 \mathrm{O}, \mathrm{CO} 2$, and $\delta 13 \mathrm{C}$ in Siberian Stone pine tree rings., Atmos.Oceanic. Opt. 24(4), 397-402.

[20] Rothman, L.S., Gordon, I.E. , Barbe, A. , Benner, D.C. , Bernath, P.F., Birk, M., Boudon,V., Brown, L.R., Compargue, A., Champion, J-P., Chance, K. , Coudert, L.N., Dana, V., Devi, V.M., Fally, S., Flaud, J.-M., Gamache, R.R., Goldman, A., Jacquemart, D., Kleiner, I., Lacome, N., Lafferty, W.J., Mandin, J.-Y., Massie, S.T., Mikhailenko, S.N., Miller, C.E., Moazzen-Ahmadi, N. , Naumenko, O.V., Nikitin, A.V., Orphal, J., Perevalov, V.I., Perrin, A., PredoiCross, A., Rinsland, C.P., Rotger, M,. Šimecková, M., Smith, M.A.H., Sung, K., Tashkun, S.A., Tennyson, J., Toth, R.A., Vandaele, A.C., and Auwera, J.Vander, 2009, J. Quant. Spectrosc. Radiat., 110, 533-572 , The HITRAN 2008 molecular spectroscopic database, Available: http://www.sci encedirect.com/science/article/pii/S0022407309000727

[21] McCarroll, D., and Loader, N.J., 2004. Stable isotopes in tree rings., Quaternary Science Reviews 23, 771-801

[22] Farquhar, G.D., O'Leary, M.H., and Berry, J.A. , 1982, On the Relationship between Carbon Isotope Discrimination and the Intercellular Carbon Dioxide Concentration in Leaves, Aust.J.Plant Physiol., 9, 121-137.

[23] Ageev, B.G., Ponomarev, Yu , and Sapozhnikova, V., , 2010, Laser Photoacoustic Detection of CO2 in Old Disc Treerings., Sensors, 10, 3305- 3313.

[24] Zuev, V.V., Savchuk D.A., Ageev, B.G., Bondarenko S.L., and Sapozhnikova, V.A., 2006, New dendrochronological parameter - the result of optoacoustic measurements of $\mathrm{CO} 2$ concentration in the annual rings of trees., Atmos. Oceanic. Opt., 19(5), 417-420.

[25] Ageev, B.G., Ponomarev, Yu.N. , and Sapozhnikova, V.A., 2009, A Trend of the $\mathrm{CO}_{2}$ concentration in tree Rings and the Atmospheric $\mathrm{CO}_{2}$., Atmos. Oceanic. Opt., 22(1), 128 134.

[26] West, J. B. , Bowen, G. J., Cerling, T. E. , and Ehleringer, J. R., 2006, Stable isotopes as one of nature's ecological recorders, Trends Ecol. Evolut. 21(7), 408-414.

[27] E. M. Galimov, 1981, Nature of Isotope Biological Fractionation, Moscow, Russia: Nauka.

[28] Ivlev, A. A., 1993, On the Fluxes of Light and Heavy Carbon in the Coupling of Photosynthesis and Photorespiration, Fiziol. Rasten. 40(6), 872-879.

[29] Ivlev, A. A., 2010, Oscillatory Character of Carbon Metabolism in Photosynthesis: Arguments and Facts, Izv. RAN, Ser. Biol., 3, 261-270. 